\title{
JNPH
}

Volume 5 No. 2 (Desember 2017)

(C) The Author(s) 2017

\section{HUBUNGAN LAMA WAKTU PAPARAN POLUTAN TERHADAP KADAR SGPT PADA PENYAPU JALAN SORE HARI DI KOTA BENGKULU}

\author{
CORRELATION WITH LONG TERM OF PATTERN EXPOSURE TO SGPT \\ RESPONSE ON STREET SWEEPER IN AFTERNOON DAYS IN BENGKULU CITY
}

\author{
SUSIWATI, ANGGITA \\ POLITEKNIK KESEHATAN KEMENTERIAN KESEHATAN BENGKULU
}

\begin{abstract}
ABSTRAK
Asap kendaraan merupakan salah satu bentuk polusi udara. Hasil dari pembakaran bahan bakar kendaraan mengeluarkan unsur logam salah satunya timbal. Dan orang yang beresiko terpapar polutan adalah pekerja penyapu jalan karena aktifitas mereka yang setiap harinya berada di jalan raya.Timbal yang masuk ke dalam tubuh pada tingkat tertentu akan menyebabkan perubahan pada beberapa molekul tubuh dan pada akhirnya akan mengganggu fungsi tubuh. Salah satu organ yang ikut mengalami perubahan akibat paparan timbal yang berlebihan adalah hati yang ditandai dengan meningkatnya kadar SGPT (Serum Glutamic Piruvic Transaminase). Sehingga peneliti tertarik untuk melihat apakah ada hubungan lama waktu paparan polutan terhadap kadar SGPT penyapu jalan di kota Bengkulu. Metode penelitian ini menggunakan desain Cross Sectional. Sampel adalah serum darah vena penyapu jalan yang kemudian diperiksa kadar SGPT nya dengan menggunakan reagen Labtest SGPT. Data dianalisis menggunakan uji $\mathrm{T}$ untuk melihat hubungan antara lama waktu paparan terhadap kadar SGPT pada penyapu jalan sore hari di Kota Bengkulu. Hasil penelitian menunjukan bahwa terdapat hubungan antara lama waktu paparan polutan terhadap kadar SGPT pada penyapu jalan sore hari. Dari uji statistik didapatkan $p$ value $(0,000)$. Ini dapat disimpulkan bahwa semakin lama waktu paparan maka semakin tinggi kadar SGPT. Penelitian ini digunakan sebagai refrensi bagi masyarakat dan petugas penyapu jalan untuk memperhatikan alat perlindungan diri yang digunakan saat bekerja untuk melindungi terpaparnya polutan secara langsung.
\end{abstract}

Kata Kunci: polutan, penyapu jalan, SGPT (Serum Glutamic Piruvic Transaminase)

\begin{abstract}
Vehicle smoke is one form of air pollution. The result of fuel combustion of vehicles removes a metal element one of them lead. And people who are at risk of exposure to pollutants are road sweepers because of their daily activities on the road. The tugs entering the body to some degree will cause changes in some of the body's molecules and will ultimately interfere with body function. One of the organ that undergoes changes due to excessive lead exposure is the liver marked by increased levels of SGPT (Serum Glutamic Piruvic Transaminase). So researchers were interested to see whether there was a long relationship of exposure to pollutants on the levels of SGPT road sweepers in the city of Bengkulu. This research method uses Cross Sectional design. The sample was a serum vein of street sweeper who then examined its SGPT levels using Lab test SGPT reagents. The data were analyzed using $\mathrm{T}$ test to see the relationship between the duration of exposure to SGPT levels in afternoon street sweeper in
\end{abstract}


Bengkulu City. The results showed that there was a relationship between the duration of exposure to pollutants to SGPT levels in afternoon street sweepers. From the statistical test obtained $p$ value $(0,000)$. It can be concluded that the longer the exposure time, the higher the levels of SGPT. This study is used as a reference for community and street sweepers to pay attention to self-protection tools used when working to protect the exposure of pollutants directly.

\section{Keywords: pollutant, street sweeper, SGPT (Serum Glutamic Piruvic Transaminase)}

\section{PENDAHULUAN}

Polusi udara terbesar terdapat di jalan raya. Asap kendaraan merupakan salah satu bentuk polusi udara tersebut. Hasil dari pembakaran bahan bakar kendaraan mengeluarkan unsur logam salah satunya Timbal. Pakar lingkungan sependapat bahwa timbal merupakan kontaminan terbesar dari seluruh debu logam di udara. Mayoritas timbal berasal dari pembakaran bahan bakar kendaraan bermotor, emisi industri, dan penggunaan cat bangunan yang mengandung timbal (Hariono, 2005).

Timbal merupakan salah satu logam berat yang bersifat racun bagi manusia, timbal yang masuk ke dalam tubuh pada tingkat tertentu akan menyebabkan perubahan pada beberapa molekul tubuh dan pada akhirnya akan mengganggu fungsi tubuh. Salah satu organ yang ikut mengalami perubahan akibat paparan timbal yang berlebihan adalah hati (Pala, 2007).

Berdasarkan data WHO (2004) sirosis hati merupakan penyebab kematian ke delapan belas di dunia, dengan prevalens 1,3\%. Cause Spesifik Death Rate (CSDR) sirosis hati di Inggris tahun 2002 sebesar 26,9 per 100.000 penduduk.

Hati merupakan jaringan tubuh yang terbesar dan organ metabolisme yang paling kompleks di dalam tubuh. Sedangkan timbal merupakan senyawa lipofilik sehingga ketika timbal di transfer ke hati akan mudah berkaitan dengan lipid dari membran sel hati dan membentuk peroksidasi lipid sehingga dalam jangka waktu lama akan menyebabkan stress oksidatif dan kerusakan pada membrane hepatosit hati (Pala, 2007).

Pemaparan dalam jangka waktu lama akan menyebabkan kerusakan sel hati.
Kerusakan sel hati ini akan mengakibatkan keluarnya enzim aminotransferase yaitu SGPT (Serum Glutamic Pyruvic Transaminase) dan SGOT (Serum Glutamic OxaloaceticTransaminase) di dalam darah (A.Hidayatet al.,2013).

Petugas kebersihan khususnya petugas penyapu jalan raya adalah orang-orang yang beresiko akan terpaparnya timbal. Dikarenakan aktivitas setiap hari yang berada di jalan raya sehingga sangat memungkinkan mereka dengan mudah terpapar timbal yang dihasilkan oleh polusi asap kendaraan yang lewat. Ketika mereka telah terpapar maka tidak menutup kemungkinan akan menyebabkan terjadinya kerusakan pada organ hati yang ditandai dengan meningkatnya nilai SGPT (Serum Glutamat Piruvat Transaminase) pada tubuh mereka. Sehingga peneliti tertarik untuk melakukan penelitian apakah ada hubungan lama waktu paparan polutan dengan kadar SGPT pada penyapu jalan di kota Bengkulu.

\section{METODE PENELITIAN}

\section{a. Tempat dan Waktu Penelitian}

Penelitian dilakukan di kota Bengkulu, sedangkan tempat pemeriksaan kadar SGPT dilakukan di laboratorium terpadu Poltekkes Kemenkes Bengkulu. Waktu penelitian mulai dari bulan November 2015 - Maret 2016.

\section{b. Populasi dan Sampel}

Populasi dalam penelitian ini adalah semua penyapu jalan yang ada di kota Bengkulu yang bekerja pada sore hari dengan jumlah 120 orang, diantaranya 70 orang yang sudah bekerja lebih dari 5 tahun dan 50 orang 
yang sudah bekerja kurang dari 5 tahun. Sampel yang digunakan dalam penelitian ini penyapu jalan di Kota Bengkulu, dengan memakai teknik Acidental Sampling di dalam pengambilan sampel. Besar sampel ditentukan dengan rumus:

Keterangan :

$\mathrm{N}$ : Besar Populasi

$\mathrm{n}$ : Besar Sampel

d:Tingkat Kepercayaan/Ketepatan yang diinginkan $(0,1)$ (Notoatmodjo, 2005).

Berdasarkan perhitungan maka ditetapkan jumlah sampel sebanyak 54 orang, diantaranya 31 orang penyapu jalan yang sudah bekerja lebih dari 5 tahun, dan 23 orang penyapu jalan yang sudah bekerja kurang dari 5 tahun dengan Kriteria inklusi sebagai berikut: Berjenis kelamin perempuan, tidak mengkonsumsi obat-obatan dalam 6 bulan terakhir, tidak merokok dan minum minuman yang mengandung Alkohol.

\section{Pemeriksaan Sampel}

\section{a. Persiapan alat dan bahan}

Alat yang digunakan dalam penelitian ini adalah kuvet, centrifuge, spektrofotometer, mikropipet, tip, tabungreaksi, raktabung, tissue, beaker gelas. Bahan yang digunakan dalam penelitian ini adalah serum sampel, reagen Labtest SGPT.

\section{b. Cara Pemeriksaan}

Disiapkan alat dan bahan yang akan digunakan, kemudian dibuat reagensia dengan cara menambahkan reagen 1 dengan reagen 2 dengan perbandingan 4:1, lalu disiapkan 2 kuvet dan dipipet kedalam kuvet 1 sebanyak $1000 \mu 1$ reagensia seagai blanko dan kedalam kuvet 2 dipipet $1000 \mu 1$ reagensia ditambahkan $100 \mu 1$ sampel lalu dihomogenkan. Kemudian diukur kadar SGPT pasien dengan spektrofotometer pada panjang gelombang 340 nm. Catat hasil.

\section{c. Pengolahan data}

Dalam pengolahan data akan dianalisis secara univariat untuk mengetahui gambaran distribusi frekuensi dari variabel. Dan juga dilakukan analisis bivariatuntuk mengetahui hubungan paparan timbal dengan kadar SGPT pada Penyapu jalan di Kota Bengkulu dengan menggunakan analisis satistik. Data yang terkumpul diolah dan disajikan dalam bentuk tabel, kemudian dianalisis secara statistik dengan Uji T.

\section{HASIL PENELITIAN}

Setelah data terkumpul kemudian data diolah secara univariat dan bivariat dengan menggukan uji $\mathrm{T}$ independent. Adapun hasil penelitiannya adalah :

\section{Analisis Univariat.}

Tabel 1 Distribusi frekuensi responden berdasarkan lama waktu paparan polutan pada penyapu jalan sore hari di kota Bengkulu

\begin{tabular}{|c|c|c|c|c|c|}
\hline Variabel & $\mathrm{N}$ Mean & Median & SD & $\begin{array}{l}\text { Nilai } \\
\text { Mini- } \\
\text { mum }\end{array}$ & $\begin{array}{l}\text { Nilai } \\
\text { Maksi- } \\
\text { mum }\end{array}$ \\
\hline $\begin{array}{c}\text { Kadar } \\
\text { SGPT } \\
\text { dengan } \\
\text { paparan } \\
<5 \text { tahun }\end{array}$ & 238,61 & 8,00 & $\begin{array}{c}2,44 \\
5\end{array}$ & 5 & 13 \\
\hline $\begin{array}{c}\text { Kadar } \\
\text { SGPT } \\
\text { dengan } \\
\text { Paparan } \\
\geq 5 \text { tahun }\end{array}$ & 3125,32 & 25,50 & $\begin{array}{c}5,77 \\
6\end{array}$ & 15 & 37 \\
\hline
\end{tabular}

Berdasarkan Tabel 1, diketahui jumlah penyapu jalan yang sudah terpapar $\geq 5$ tahun lebih banyak dengan persentase $57 \%$ dari pada jumlah penyapu jalan yang sudah bekerja selama $<5$ tahun.

Tabel 2 Distribusi Rata-rata kadar SGPT penyapu jalan sore hari di kota Bengkulu 


\begin{tabular}{ccc}
\hline Lama WaktuPaparan & $\mathrm{N}$ & Persentase \\
\hline$<5$ tahun & 23 & $43 \%$ \\
\hline$\geq 5$ tahun & 31 & $57 \%$ \\
\hline
\end{tabular}

Berdasarkan table 2 terlihat rata-rata kadar SGPT pada responden dengan lama paparan $\geq 5$ tahun lebih tinggi dari pada responden dengan masa kerja $<5$ tahun.

\section{Analisis Bivariat}

Tabel 3 Hubungan lama waktu paparan polutan terhadap kadar SGPT pada penyapu jalan sore hari di kota Bengkulu

\begin{tabular}{llllll}
\hline $\begin{array}{c}\text { Lama Waktu } \\
\text { Paparan }\end{array}$ & $\mathrm{N}$ & Mean & SD & SE & $\begin{array}{c}\mathrm{P} \\
\text { value }\end{array}$ \\
\hline $\begin{array}{c}\text { Kadar SGPT } \\
<5 \text { tahun }\end{array}$ & 23 & 8,61 & 2,445 & 0,462 & \\
\hline $\begin{array}{l}\text { Kadar SGPT } \\
\geq 5 \text { tahun }\end{array}$ & 31 & 25,32 & 5,776 & 1,162 & 0.000 \\
\hline
\end{tabular}

Berdasarkan tabel 3 terlihat bahwa hasil uji statistik didapatkan nilai $\mathrm{P}=0,000 \alpha=0,05$, artinya ada hubungan lama waktu paparan polutan terhadap kadar SGPT penyapu jalan sore di kota Bengkulu.

\section{PEMBAHASAN}

Hasil penelitian menunjukkan bahwa terdapat perbedaan kadar SGPT pada penyapu jalan sore hari dengan lamanya waktu paparan polutan. Hal ini berarti bahwa semakin lama watu paparan maka semakin tinggi pula kadar SGPT pada penyapu jalan tersebut.

Hasil pemeriksaan dari 2 kelompok sampel diantaranya penyapu jalan dengan lama waktu paparan $<5$ tahun dan penyapu jalan dengan lama waktu paparan $\geq 5$ tahun menunjukkan perbedaan kadar. Dimana kadar SGPT pada penyapu jalan dengan lama waktu paparan $<5$ tahun lebih rendah dibandingkan dengan $\mathrm{p}$ kadar SGPT penyapu jalan dengan lama waktu paparan $\geq 5$ tahun.

Berdasarkan penelitian sebelumnya, tingginya kadar timbal dalam darah akan mengakibatkan tingkat kerusakan sel hati semakin tinggi pula karena timbal yang diedarkan oleh darah akan berikatan dengan lipid dari membran sel hati membentuk peroksida lipid dan menginduksi pembentukan radikal bebas. Hal ini sesuai dengan hasil penelitian Gajawat et al (2006).

Penelitian sejenis juga pernah dilakukan oleh Fidiyatun et al. pada tahun 2013dimana hasil penelititan menunjukkan ada hubungan antara kadar Timbal dalam darah dengan kejadian gangguan fungsi hati yang ditandai dengan meningkatnya kadar enzim SGPT dan SGOT.

Polutan yang mengandung timbal yang masuk ke dalam tubuh akan menjadi suatu senyawa kimia $\mathrm{Pb}^{2+}$ yang memiliki atom bebas pada lapisan luarnya. Timbal berubah menjadi radikal bebas karena memiliki atom yang bebas dan berusaha untuk melengkapi lapisan luarnya agar lebih stabil dengan mengikat molekul lain dari organ tubuh.

Dalam mencapai kestabilan tersebut $\mathrm{Pb}^{2+}$ akan mengikat lipid dari membran hepatosit hati dan membentuk peroksida lipid sehingga dalam jangka waktu lama akan menyebabkan stress oksidatif dan kerusakan pada membran hepatosit hati (Pala, 2007).

Stress oksidatif yang diakibatkan timbal, terlebih dahulu menyerang membran plasma hati yang ditandai dengan meningkatnya kadar enzim SGPT dua kali lipat dibandingkan dengan kelompok yang tidak terpapar timbal hal ini sesuai dengan analisis data pada penelitian yang dilakukan oleh A.Hidayat et al pada tahun 2013.

Pengaruh timbal yang masuk kedalam tubuh manusia khususnya pada penyapu jalan yang menghirup udara yang mengndung timbal dari asap kendaraan dan komponen timbal yang berasal dari aspal. Timbal terhirup terus menerus selama kurun waktu bertahun tahun dengan frekuensi bekerja setiap harinya enam jam. Keracunan yang ditimbulkan sebagai akibat kontaminasi logam timbal adalah sebagai berikut :

a. Meningkatkan protoprophilin dalam sel darah-darah. 
b. Memperpendek umur sel darah merah.

c. Menurunkan jumlah sel darah merah.

d. Menurunkan kadar retikulosit (sel darah merah yang masih mudah).

e. Meningkatkan kandungan Logam $\mathrm{Fe}$ dalam darah.

f. Memberikan perubahan terhadap fungsi organ hati.

Petugas kebersihan khususnya petugas penyapu jalan raya adalah orang-orang yang beresiko akan terpaparnya timbal.

Dikarenakan aktivitas setiap hari yang berada di jalan raya dengan lama waktu 6 jam dalam sehari. Sehingga sangat memungkinkan mereka dengan mudah terpapar timbal yang dihasilkan oleh polusi asap kendaraan yang lewat. Berdasarkan observasi saya pada saat pengambilan sampel, di antara 54 sampel yang saya temukan 39 di antaranya tidak menggunakan alat perlindungan diri yang lengkap seperti masker, sarung tangan, baju seragam, topi dan sepatu. Maka ketika mereka telah terpapar tidak menutup kemungkinan akan menyebabkan terjadinya kerusakan pada organ hati yang ditandai dengan meningkatnya nilai SGPT (Serum Glutamat Piruvat Transaminase) pada tubuh mereka.

Hubungan lama waktu paparan polutan terhadap kadar SGPT pada penyapu jalan sore hari di Kota Bengkulu di karenakan pemaparan timbal dalam jangka waktu cukup lama dapat mengakibatkan kerusakan hati.

Distribusi timbal yang diabsorbsi di dalam tubuh diangkut oleh darah dan diedarkan ke organ-organ tubuh, dan sebanyak 95\% timbal dalam darah akan diikat eritrosit. Timbal plasma akan diedarkan ke jenis jaringan yaitu jaringan lunak terutama hati yang menyebabkan kerusakan sel hati yang mengakibatkan keluarnya enzim aminotransferase yaitu SGOT ( Serum Glutamic Oxaloacetic Transaminase) dan SGPT ( Serum Glutamic Pyruvic
Transaminase) di dalam darah. Enzim ini sering dikenal sebagai penanda kerusakan atau kelainan sel hati (Gurer et al, 2000).

SGPT (Serum Glutamic Piruvic Transaminase) adalah suatu enzim yang mengkatalisir reversible gugus alfa amino, alanin untuk menjadi asam gkutamate dan asam piruvat. Peningkatan kadar enzim dalam darah umumnya terjadi jika ada kerusakan sel yang mengandung enzim, serta adanya perubahan permeabilitas dinding sel.

\section{KESIMPULAN}

Dari serangkaian kegiatan penelitian yang dilakukan untuk mengetahui hubungan lama waktu paparan polutan terhadap kadar SGPT pada penyapu jalan sore hari di kota Bengkulu, dapat disimpulkan bahwa :

1. Ada hubungan antara lama waktu paparan terhadap kadar SGPT pada penyapu jalan sore hari di kota Bengkulu.

2. Pada penyapu jalan sore hari dengan lama waktu paparan $<5$ tahun , hasil pemeriksaan kadar SGPT rendah atau masih dalam batas normal. Pada penyapu jalan sore hari dengan lama waktu paparan $\geq 5$ tahun, hasil pemeriksaan kadar SGPT mengalami kenaikan dibandingkan penyapu jalan dengan lama waktu paparan $<5$ tahun.

\section{SARAN}

Dari penelitian yang telah dilakukan, penulis ingin memberikan saran :

1. Disarankan kepada para penyapu jalan untuk lebih memperhatikan lagi dalam penggunaan alat perlindungan diri yang lebih lengkap agar mengurangi terpapar polutan secara langsung.

2. Disarankan kepada pemerintah atau instansi terkait agar lebih melengkapi lagi alat perlindungan diri yang diberikan kepada petugas kebersihan khusunya 
penyapu jalan.

3. Disarankan kepada peneliti lain untuk penelitian lebih lanjut dengan jumlah sampel yang lebih banyak dan wilayah cakupan yang lebih luas.

\section{DAFTAR PUSTAKA}

A.Hidayat, Wulan Christijanti \& Aditya Marianti. 2013. Pengaruh Vitamin E Terhadap Kadar SGPT dan SGOT Tikus Putih Galur Wistar Yang di Papar Timbal. Unnes Journal of Life Science 2 (1). Jurusan Biologi, Fakultas MIPA, Universitas Negeri Semarang. Indonesia.

Hariono B. 2005. Efek Pemberian Plumbum

(Timah Hitam) Anorganik pada Tikus Putih (Rattus norvegicus), J. Sain Vet Vol 23 No. 2 Th. 2005, Bagian Patologi Klinik FKH UGM, Yogyakarta : 107108.

Notoatmodjo, S. 2010. Metodologi Penelitian Kesehatan. Jakarta : Rineka Cipta.

Pala FS \& Kiymet T. 2007. Free radical : Our Enemies or friends?. Advances in Molecular Biology. (1) : 63-69.

Sipos P, Szentmihaly K, Feher E \& AbazaM. 2003. Some Effect of Lead Contamination on Liver and Gallblader Bile. Acta Biologica Szegebdiensis. 47(14) : 139-142.

Sibuea WH. 2005. Ilmu Penyakit Dalam. Jakarta. PT Asdi Mahasatya.

Suciani, Sri. 2007. Kadar Timbal Dalam Darah Polisi Lalu Lintas Dan Hubungannya Dengan Kadar Hemoglobin (Studi pada Polisi Lalu Lintas yang Bertugas di Jalan Raya Kota Semarang). Tesis Pascasarjana, Universitas Diponegoro. 